2014

\title{
The Costs of Lost Privacy: Consumer Harm and Rising Economic Inequality in the Age of Google
}

Nathan Newman

Follow this and additional works at: http://open.mitchellhamline.edu/wmlr

\section{Recommended Citation}

Newman, Nathan (2014) "The Costs of Lost Privacy: Consumer Harm and Rising Economic Inequality in the Age of Google," William Mitchell Law Review: Vol. 40: Iss. 2, Article 12.

Available at: http://open.mitchellhamline.edu/wmlr/vol40/iss2/12

This Article is brought to you for free and open access by the Law Reviews and Journals at Mitchell Hamline Open Access. It has been accepted for inclusion in William Mitchell Law Review by an authorized administrator of Mitchell Hamline Open Access. For more information, please contact sean.felhofer@mitchellhamline.edu.

(c) Mitchell Hamline School of Law

\section{$\mathrm{MH}$}

MITCHELL | HAMUINE OPEN ACCESS senod of the mitchellhamline.edu 


\title{
THE COSTS OF LOST PRIVACY: CONSUMER HARM AND RISING ECONOMIC INEQUALITY IN THE AGE OF GOOGLE
}

\author{
Nathan Newman ${ }^{\dagger}$
}

I. INTRODUCTION: LOSS OF PRIVACY AND CONSUMER HARM ... 850

A. The Pervasive Consumer Harm from Google's Facilitation of User Targeting by Its Advertisers..................................... 852

B. Using Antitrust to Address Economic Inequality Due to Monopoly.

II. THE FAILURE OF THE GOOGLE "MARKET" FOR USER DATA .. 855

A. Users Overestimate the Value Added by Google's Services and Do Not Receive the Full Economic Value of the Data They Share with Google.....

B. Users Undervalue the Economic Value of the Data They

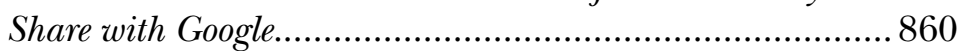

C. Why Aren't Users Paid for Their Data?................................ 863

III. Why USER DATA IS SO USEFUl TO ADVERTISERS: "PAIN POINTS” AND THE CONSUMER HARM OF PRICE DISCRIMINATION FACILITATED BY A MONOPOLY PLAYER

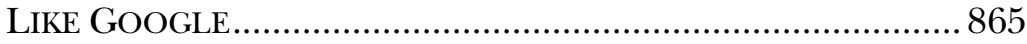

IV. THE CASE FOR LEGAL ACTION ON CONSUMER HARM FROM PRICE DISCRIMINATION

V. SubPrime Mortgages, "Ambulance Chasers AND

SNAKE OIL SALESPEOPLE": HOW ONLINE ADVERTISING UNLEASHES THE "TAWDRY" SIDE OF CAPITALISM .

A. Racial and Economic Profiling Online ............................. 877

B. Google and the Subprime Mortgage Crisis.......................... 879

$\dagger \quad$ Nathan Newman is a Fellow at New York University's Information Law Institute. He received his JD from Yale Law School and his PhD in Sociology from the University of California at Berkeley and has written extensively about public policy and technology in a range of academic and popular journals, including publishing a book, Net Loss: Internet Prophets, Private Profits, AND the Costs TO COMMUNiTy (2002). 
C. Google's Continued Role in Facilitating Financial

Exploitation of Consumers.

D. Promoting Illegal Drug Advertisements Earned Google One of the Largest Civil Forfeitures in American History....

VI. CONCLUSION: THE BROAD CONSUMER HARM FROM

GOOGLE'S MONOPOLY IS NOT BEING CORRECTED BY MARKET MECHANISMS

A. Remedies to Address Consumer Harm from Lost Privacy

Online.

B. How Government Intervention Addresses Rising Economic Inequality

\section{INTRODUCTION: LOSS OF PRIVACY AND CONSUMER HARM}

Search and related online services have provoked debates in recent years about the loss of individual privacy, but this is often framed more around an individual sense of unease at the surveillance of peoples' private lives than how a shift in knowledge about individuals to corporate hands should force us to reevaluate our economic models and regulatory tools.

The lack of analysis of the consumer harm from loss of data privacy is one reason Google, despite its clear dominance of search advertising, has escaped antitrust prosecution so far in the United States. An antitrust case must show harm to consumers, ${ }^{1}$ and Google's defenders often deny that consumers lose anything from their interaction with Google. "It's . . impossible to find any way in which consumer welfare is currently being harmed by Google," writes George Mason University's Adam Thierer, "[a]ll their products are free and constantly evolving." ${ }^{2} \mathrm{Or}$ as David Balto

1. Brook Group Ltd. v. Brown \& Williamson Tobacco Corp., 509 U.S. 209, 224 (1993) ("It is axiomatic that the antitrust laws were passed for "the protection of competition, not competitors."”); Reiter v. Sonotone Corp., 442 U.S. 330, 343 (1979) ("Congress designed the Sherman Act as a "consumer welfare prescription.”); Brown Shoe Co. v. United States, 370 U.S. 294, 344 (1962) (“It is competition, not competitors, which the [Sherman] Act protects."); see also United States v. Microsoft Corp., 253 F.3d 34, 58 (D.C. Cir. 2001) (per curiam) ("[T]o be condemned as exclusionary, a monopolist's act must . . . harm the competitive process and thereby harm consumers. In contrast, harm to one or more competitors will not suffice.").

2. Adam Thierer, Can There Be a Market for Unpaid Search Results and Could 
elegantly puts it, "Consumers' pocketbooks do not see Google as any type of monopolist." Complaints about Google are largely dismissed as the whining of competitors, who might gain at the expense of Google, but not to the benefit of consumers, according to these Google defenders."

When the Federal Trade Commission (FTC) found no antitrust violation in Google's dominance of "search" in January 2013, the FTC majority similarly argued for their position largely from finding no consumer harm from how Google might manipulate search results to the disadvantage of potential rival websites. ${ }^{5}$ Yet the analysis of the FTC's majority opinion looked only at users' interests in accurate search results without ever analyzing how Google's control of user data might impact consumer welfare. Only FTC Commissioner J. Thomas Rosch expressed in a partial dissent the concern that Google's "monopoly or near-monopoly

Google Be Classified as a Public Utility?, Antitrust \& Competition POL'y Blog (May 21, 2012), http://lawprofessors.typepad.com/antitrustprof_blog/2012 /05/can-there-be-a-market-for-unpaid-search-results-and-could-google-be-classified -as-a-public-utility-c-1.html. See also Jim Miller \& Dan Oliver, An Antitrust Probe of Google?, NAT'L REV. ONLINE (Dec. 20, 2011, 5:00 PM), http://www.nationalreview .com/bench-memos/286349/antitrust-probe-google-jim-miller (“[C] onsumers are reaping enormous benefits from the free service designed to reflect their choices.”).

3. David Balto, Google Is No Microsoft, Huffington Post (June 30, 2011, 6:41 PM), http://huff.to/jfDamv (“[C] onsumers face zero switching costs!”).

4. See U.S. DeP'T of Justice, Antitrust Division Policy Guide to Merger REMEDIES 2 (2011), available at http://www.justice.gov/atr/public/guidelines /272350.pdf (noting that a "remedy should focus on preserving competition, not protecting individual competitors"); Geoffrey Manne \& Berin Szoka, Some MuchNeeded Antitrust Skepticism on Senate Letter Urging FTC Google Investigation, TRUTH ON MARKET (Dec. 20, 2011), http://truthonthemarket.com/2011/12/20/some -much-needed-antitrust-skepticism-on-senate-letter-urging-ftc-google-investigation/ (" $[\mathrm{H}]$ arm to competitors is not the same thing as harm to consumers or competition more generally ....”).

5. Google Inc., FTC File No. 111-0163, at 3 (Jan. 3, 2013), http://www .ftc.gov/sites/default/files/documents/public_statements/statement-commission -regarding-googles-search-practices/130103brillgooglesearchstmt.pdf (statement of the Federal Trade Commission regarding Google's search practices) ("[C]hanges to Google's search algorithm could reasonably be viewed as improving the overall quality of Google's search results . ...”).

6. Id. at 3 . 
power in the search advertising market" is derived from control of user data obtained through deceptive means.

Expanding on the concerns expressed in Rosch's dissent, this article will detail how understanding the dynamics of data mining and behavioral targeting reveal the clear harm to consumers from Google's monopoly of the online search advertising market.

\section{A. The Pervasive Consumer Harm from Google's Facilitation of User Targeting by Its Advertisers}

The most obvious harm is the undermining of competition in the online advertising market, where higher prices charged to advertisers inevitably get passed onto consumers in the form of higher prices for the advertised goods and services they buy. I have detailed the clear monopoly dominance of the search advertising sector by Google and the ensuing general consumer harm from such dominance elsewhere. ${ }^{8}$ So, this article will focus on the more pervasive harm to consumers from the stunted "market" for user data itself, where lack of vigorous competition means users too readily share that data at too low a price-usually for free in exchange for software services that cost companies like Google far less than the value of the user data they collect.

Linked to that extraction of user data is the way Google helps facilitate the engagement of advertisers in user profiling that aids those companies in extracting the maximum profit possible from consumers in the overall economy. Advertisers can deliver ads not just to the users most likely to be interested in the product, but can tailor prices for individual consumers in ways that can maximize the revenue extracted from each purchaser. A story in 2012 about the travel site Orbitz steering Mac owners to higher-priced hotels and PC owners to lower-priced ones is a basic example of such a

7. Google Inc., FTC File No. 111-0163, at 1 n.1 (Jan. 3, 2013) (Rosch, Comm'r, concurring and dissenting), http://www.ftc.gov/sites/default/files /documents/public_statements/concurring-and-dissenting-statement-commission er-j.thomas-rosch-regarding-googles-search-practices/130103googlesearchstmt.pdf (concurring and dissenting statement of Commissioner J. Thomas Rosch Regarding Google's Search Practices) [hereinafter Rosch's Statement].

8. Nathan Newman, Search, Antitrust, and the Economics of the Control of User Data, 31 YALE J. ON REG. (forthcoming Summer 2014), available at http:/ / papers.ssrn.com/sol3/papers.cfm?abstract_id=2309547. 
strategy, ${ }^{9}$ although the practice encompasses everything from offering promotional discounts only to selected customers to targeting subprime mortgage offers online at likely victims-which were advertised heavily on Google during the company's economic rise. ${ }^{10}$ There is also strong evidence, including massive financial sanctions against Google, that this targeting of ads empowers criminal and "tawdry" (in Internet analyst Jaron Lanier's words) companies to exploit users online. At its worst, this data-miningsupported targeting of consumers may be empowering racial profiling in new and disturbing ways as well. ${ }^{12}$

Joseph Stiglitz and allied economic thinkers argue increasing information asymmetry feeds increasing economic inequality as well, such that the "result from the new information economics is that issues of efficiency and equity cannot easily be delinked." "The fact that many of Google's largest advertising customers in the midpart of the last decade were linked to the subprime mortgage industry, as will be detailed later in this article, ${ }^{14}$ is just one indicator that understanding the dynamics of the search advertising sector may give insight into larger theoretical problems of market failure, the harm from predatory firms, and why we have seen rising economic inequality in the economy over recent decades.

As this article will detail, Google's ascension as a dominant player across a range of Internet services is giving its advertisers a whole series of tools to target customers based on their individual preferences, physical location, and other characteristics. This is part of a rising asymmetry in knowledge between companies and their customers across the economy due to the rise of data mining and the power of "big data."

9. Dana Matiolli, On Orbitz, Mac Users Steered to Pricier Hotels, Wall St. J., June 26, 2012, at A1, available at LEXIS.

10. See infra Part V.C.

11. John Brockman, The Local-Global Flip, or, "The Lanier Effect": A Conversation with Jaron Lanier, EDGE (Aug. 29, 2011), http://edge.org/conversation/the-local -global-flip.

12. See infra Part V.A.

13. Joseph E. Stiglitz, Information and the Change in the Paradigm in Economics, 92 Am. Econ. Rev. 460, 479 (2002); see also George A. Akerlof, The Market for Lemons: Quality Uncertainty and the Market Mechanism, 84 Q.J. ECON. 488, 488-500 (1970).

14. See infra Part IV. 


\section{B. Using Antitrust to Address Economic Inequality Due to Monopoly}

With the information asymmetries driven by data mining and behavioral profiling, Google facilitates exploitation of user data in the online marketplace in ways that de facto transfer wealth between the broader population to the company's corporate advertisers. The primary user harm identified by this analysis is not just narrow economic profits returned to Google, but a much more fundamental enrichment of its advertisers at the expense of average consumers' wallets and privacy. Given that, this analysis also challenges the narrow conception of antitrust as a tool for maintaining competition in the abstract and argues for it being seen as a broader tool for promoting economic equality in more structural terms.

While many antitrust scholars such as Robert Bork have seen antitrust action as a limited tool for restoring the natural allocative efficiency of the market, ${ }^{15}$ information economics scholars such as Stiglitz argue that information asymmetry creates continual disruptions of any "natural" market equilibrium. With no simple, single equilibrium price and no single measure of "efficiency" based on such an equilibrium, any pure efficiency analysis fails. This is especially true in information markets themselves like online advertising, where promoting more demand and convincing customers to pay a higher price than they might have under any supposed equilibrium price is the goal of advertising in the first place. Advertising's very existence is based on the reality-often ignored in Chicago School-style economics-that individuals are not perfectly informed of prices and quality differences, so there is not necessarily an equilibrium price. ${ }^{16}$ And in a case where firms can differentiate between customers, as Google allows through behavioral profiling based on user data, traditional neoclassical market analyses further fail as sellers slice markets into segments based as much on the relative ignorance of different market

15. See Robert Bork, The Antitrust Paradox 107-15 (1978).

16. S. Salop \& J.E. Stiglitz, The Theory of Sales: A Simple Model of Equilibrium Price Dispersion with Identical Agents, 72 AM. ECON. REv. 1121, 1121 (1982) (noting where "information is costly to gather ... [and] individuals may not be perfectly informed about the prices (or qualities) of what is being sold . . the law of the single price does not obtain"). 
segments of consumers as on any abstract demand curve. ${ }^{17}$ Most important to antitrust analysis, strategic decisions by dominant sellers themselves can shape the multiple equilibria prices in ways that can further entrench their dominance.

Other scholars have argued that the original intent of antitrust was not to act as a meta-consumer protection law simply policing an ideal market, but was focused more specifically on challenging the wealth transfers from the public to monopolists and oligopolists. "Congress passed the antitrust laws to further economic objectives, but primarily objectives of a distributive rather than of an efficiency nature," writes Robert Lande, "[i]n other words, Congress was concerned principally with preventing 'unfair' transfers of wealth from consumers to firms with market power." ${ }^{19}$ In the case of search advertising, this article will illustrate how "unfair" can be understood operationally in this case in terms of a dominant search advertising company exploiting consumer ignorance through data mining to enrich both itself and its advertisers at consumer expense.

\section{THE FAILURE OF THE GOOGLE “MARKET” FOR USER DATA}

Most defenders of Google argue that users engage in a rational market exchange. In exchange for providing some personal data to Google, those users get access to a valuable service. ${ }^{20}$ However,

17. Id. at 1122-23 ("[I]f firms have access to devices . . . which allow the firm to differentiate between different groups in the population ... and, if it is costly to enter the market, no equilibrium exists."); Steven Salop, The Noisy Monopolist: Imperfect Information, Price Dispersion and Price Discrimination, 44 REv. ECON. STUD. 393, 393 (1977) ("[Cost] dispersion acts as a costly device for sorting consumers into submarkets to permit price discrimination.”); see Rosa-Branca Esteves \& Joana Resende, Competitive Targeted Advertising with Price Discrimination (Universidade do Minho Núcleo de Investigação em Políticas Económicas, Working Paper No. 08, 2011), available at http://ideas.repec.org/p/nip/nipewp/08-2011.html (discussed infra in Part III).

18. J. Stiglitz \& A. Weiss, Alternative Approaches to Analyzing Markets with Asymmetric Information: Reply, 73 AM. ECON. Rev. 246, 246-49 (1983).

19. Robert Lande, Wealth Transfers as the Original and Primary Concern of Antitrust: The Efficiency Interpretation Challenged, 34 HASTINGS L.J. 65, 68 (1982); see also Louis B. Schwartz, "Justice" and Other Non-Economic Goals of Antitrust, 127 U. PA. L. REv. 1076, 1078 (1979) (stating that American imposition of antitrust measures in post-war Japan and Germany was a political move to shift power).

20. Robert Bork, Antitrust and Google, CHI. TriB., Apr. 6, 2012, at 19, available 
assuming that the market is functioning in such a case requires (1) that those users properly value the benefits they receive from Google, (2) that they properly price their personal information and the opportunity cost of giving it up, and (3) that there are no economic byproducts of Google's monopoly control of user data that reduce consumer welfare more generally. As this section will detail, there is strong evidence that users do not properly calculate any of those three factors in the exchange with Google, leading to large costs to the public from Google's dominance.

Without viable alternatives to Google, you end up with a stunted "market" for valuing user privacy, so Google feels less and less compunction about violating personal privacy to benefit its advertising customers. While scholars like Frank Pasquale have noted the danger of analyzing loss of privacy and other harms from Google in just economic terms since that misses many of its noneconomic harms, ${ }^{21}$ those clear economic harms merit antitrust

at 2012 WLNR 7311753 ("No agency or critic has articulated a coherent theory of how Google harms consumers. . . . Search algorithms speed to consumers what they most likely want and direct advertisers to consumers most likely to want to buy from them.”). Geoffrey Manne and Joshua Wright argue that search advertising is just like any form of advertising, where the goal is to help consumers find advertising for products that might interest them. Geoffrey A. Manne \& Joshua D. Wright, Google and the Limits of Antitrust: The Case Against the Case Against Google, 34 HARv. J.L. \& Pub. POL'Y 171, 222 (2011) (“[A]ll forms of advertising-and related endeavors like store placement and design—are about bringing buyers and sellers together by minimizing some of the transaction costs that otherwise keep them apart."); see also Eric Goldman, A Coasean Analysis of Marketing, 2006 WIS. L. REV. 1151, 1162-64 (providing a formulaic approach to evaluating consumer utility derived from marketing exposure).

21. Frank Pasquale, Beyond Innovation and Competition: The Need for Qualified Transparency in Internet Intermediaries, 104 Nw. U. L. REv. 105, 143 (2010) ("Engaging in a cost-benefit analysis diminishes privacy's status as a right."); see also C. Edwin Baker, Media Concentration: Giving up on Democracy, 54 FlA. L. REV. 839, 857 (2002) (noting antirust largely ignores loss to public from monopoly "power over the content available for consumer choice"). Pasquale also details many noneconomic harms from Google's search monopoly, from mistaken same-name reputational harms to unearthing credit reports or expunged records. Pasquale, supra, at 114. Siva Vaidhyanathan also analyzes a wide range of non-economic harms of Google's concentrated dominance as well. See generally SIVA Vaidhyanathan, The Googlization of Everything (and Why We SHOuld Worky) (2011). 
action even if other regulatory actions or legislation may be needed to address the full gamut of privacy losses. ${ }^{22}$

The deeper harm to consumers from Google's power in the market-and one that is at the heart of the increasing economic inequality in our society-is the way Google's profiling of its users for advertisers allows the kind of predatory marketing we saw in the subprime housing bubble globally and in a range of other sectors. Online profiling based on user data allows seedier companies, from subprime mortgage lenders to payday lenders, to target the most naïve and vulnerable potential consumers and facilitate new forms of price discrimination even by more legitimate firms that allow those companies to extract the highest potential price for goods and services from each customer. ${ }^{23}$ The result is harm to those victimized consumers and is a likely explanation for the more pervasive increase in economic inequality.

\section{A. Users Overestimate the Value Added by Google's Services and Do Not Receive the Full Economic Value of the Data They Share with Google}

Without discounting the value added by Google's aggregation services in search and a range of its other products, a basic truth is that most of the value delivered by Google is access to other peoples' labor and knowledge, most of which Google accesses for free itself. With Google seeming to be the gateway to the Internet itself, whether in search, YouTube videos, or Android apps, its value can seem literally incalculable.

Media studies professor Clay Shirky details in Cognitive Surplus how profound a shift in our models of production and markets is underway in a world where people can access the fruits of not only commercial production but, even more dramatically, "user generated content" created outside any traditional marketplace.

22. See Frank Pasquale and Oren Bracha, who have promoted just such an alternative regulatory approach to address such non-antitrust concerns about a search monopoly in Federal Search Commission? Access, Fairness, and Accountability in the Law of Search, 93 CORNELL L. REV. 1149 (2008).

23. See infra Parts III, V.

24. See infra Part VI.

25. Clay Shirky, Cognitive Surplus: Creativity and Generosity in a CONNECTED AGE 27 (2010) (“[T] he wiring of humanity lets us treat free time as a shared global resource, and lets us design new kinds of participation and sharing that take advantage of that resource."). 
Where home production has been largely marginal in modern society, the Internet suddenly makes "free time" incredibly valuable when aggregated, yet returns little of that value to those producers. Companies like Google take advantage of this peer production in ways writer Nicholas Carr has referred to as "digital sharecropping," where the Internet "provides an incredibly efficient mechanism to harvest the economic value of the free labor provided by the very many and concentrate it into the hands of the very few." ${ }^{26}$

The incredibly outsized stock valuations of web-based firms such as Amazon (with its user-generated product reviews), Facebook (with its user-generated content and social links), and Google (with its ability to search for others' content, usergenerated YouTube videos, etc.) can best be understood in terms of the cognitive surplus each is harvesting. ${ }^{27}$ It is one way to explain how Google can have a stock market capitalization roughly the same as AT\&T, while employing one-fifth as many employees. ${ }^{28}$ While such social media companies provide a service, they are in fact using what is a relatively small investment to leverage the value of others' free labor by becoming the gateway for users to other online user's content. ${ }^{29}$ Given that its content largely comes from other people and companies and is delivered over the common Internet system, this is one argument for applying common-carrier rules to the company and the right of the public for regulations

26. Nicholas Carr, Sharecropping the Long Tail, Rough Type (Dec. 19, 2006, 8:55 AM), http://www.roughtype.com/?p=634; see also VAIDHYANATHAN, supra note 21, at 30 ("Google is taking a free ride on the creative content of billions of content creators.”).

27. Conversely, when the free contributions to a social network dry up, a once highly-valued company can become nearly worthless. The social news site Digg, for example, was valued at one point at $\$ 160$ million, but was sold for $\$ 500,000$ in 2012 as its community of users contributing content "started to drift away in early 2010." See Joseph Walker \& Spenser Ante, Once a Social Media Star, Digg Sells for \$500,000, WALL ST. J., July 13, 2012, at B3, available at LEXIS.

28. See Nathan Newman, Job Creation Will Come from the Wires, Not the Software of Broadband Internet, Huffington Post (Oct. 10, 2011, 3:30 PM), http://www.huffingtonpost.com/nathan-newman/corporate-outsourcing-jobs_b _1005269.html.

29. VAIDhyANATHAN, supra note 21, at 16 (detailing how Google gained its dominance because it delivers "video and text to users, even if much of that content is hosted on other institutions' sites"). 
ensuring fair and equitable access to the content that Google is leveraging itself for free. ${ }^{30}$

Google's innovation in search technology was, in fact, built around harvesting the diffuse labor of people across the Internet. Its original PageRank algorithm used the links to other websites created by website creators across the Internet as a tool to assess and rank the likely value of websites containing similar information or keywords. ${ }^{31}$ This system of highly ranking websites valued by other users has been enhanced by also measuring what sites Google's own users click on when they make a particular search. ${ }^{32}$ Each click adds to the algorithm that can direct users with similar searches and interests to see the same link become highly ranked when they make a search as well. The more people find and use other people's content via Google, the better Google's algorithm becomes, reinforcing the precision and strength of its search engine vis-à-vis any challenger search technology, which would lack access to the network of users and the information they generate on search preferences. ${ }^{33}$ Other Google services such as YouTube or Gmail play out much the same dynamic, with users gaining important technological advantages from using Google but ultimately getting greater value from the labor of other users, thereby confusing any simple economic valuation of what Google is providing. This also apparently confuses many analysts who attribute greater innovation to Google when its search quality advantages are in fact due to the monopoly dominance that gives it such a disproportionate share of user data.

What Google, Facebook, and other online gateways are tapping is a psychological drive to share with others that is quite distinct from the simple self-interested economic market models most economists depend upon for understanding how value in both production and consumption is measured and where the motivation for its creation is derived. ${ }^{34}$ To encourage its users to

30. See Newman, supra note 8, (manuscript at 68-69).

31. VAIDHYANATHAN, supra note 21, at 21.

32. See James Grimmelmann, The Google Dilemma, 53 N.Y. L. SCH. L. REV. 939, 941-42 (2008/09); Pasquale, supra note 21, at 116 n.50.

33. See Pasquale, supra note 21, at 116 n.50.

34. Scholars Yochai Benkler and Helen Nissenbaum have described how "common-based peer production" systems tap a whole complex of social desires for autonomy and competence whose rewards are more related to social 
share content freely on its services, Google has publicly adopted multiple markers of peer-based production. Most famously, Google adopted in its early mission statement that it would "make money without doing evil,", or more simply, "don't be evil" as stated in the first words of Google's code of conduct. ${ }^{36}$ Combined with ostensibly providing its own free content to users, this mantra was a clear signal to users that the company was "one of them" in promoting shared value through collaboration. ${ }^{37}$ However, Google could seem to be acting in a collaborative way with its users because its key advertising revenue source was based on collecting-and not sharing-intimate user data from those "collaborators."

\section{B. Users Undervalue the Economic Value of the Data They Share with Google}

If users attribute too much of the value they gain from accessing online content to Google, they also clearly underestimate the economic value of the personal data they share with Google in exchange for accessing its services. Because there is no price paid for the data by Google, or paid by users for the Google products those users use, the result is a zero price barter exchange. As David Evans notes, this results in "conundrums and confusion in antitrust analysis" since gains or losses on price, quality, and other factors for users in a zero price exchange are disguised. ${ }^{38}$ Standard antitrust analysis loses the price measure for evaluating such issues, since, as Evans highlights, "[five] percent of zero is still zero." 39

On the face of it, the fact that Google is de facto involved in a barter relationship with its users-trading its tools for their

relationships than traditional market forces. See generally Yochai Benkler \& Helen Nissenbaum, Commons-Based Peer Production and Virtue, 14 J. POL. PHIL. 394 (2006).

35. Ten Things We Know to Be True, Google, http://www.google.com/about /company/philosophy/ (last visited Dec. 8, 2013).

36. Code of Conduct, Google, http://investor.google.com/corporate/code-of -conduct.html (last visited Dec. 8, 2013).

37. See Jeffrey Van Camp, Is Google Still Worth Our Love, or Has It Become Another Selfish Corporation?, Digital TREnds (Mar. 15, 2012), http://www .digitaltrends.com/opinion/is-google-still-worth-our-love-or-has-it-become-another -selfish-corporation.

38. David S. Evans, The Antitrust Economics of Free, 7 COMPETITION POL'y INT'L 71, 72 (2011).

39. Id. 
individual private information-is a pretty clear indication that users are unlikely to be getting the full market value of their dataand means that analyzing the situation in terms of economic models of market exchange makes little sense. ${ }^{40}$ Like most barter economies, pricing is opaque and creates massive opportunities for economic arbitrage by the sophisticated side of the barter transaction-i.e., Google. Essentially Google users are the primitive tribes of the Internet, accepting the shiny trinkets of Gmail and free search in exchange for their privacy. As anthropologists will attest about such primitive systems of nonmarket exchange, they can be dynamic and productive in ways market economies may not be in certain situations, ${ }^{41}$ just as writers like Clay Shirky, Yochai Benkler, and Helen Nissenbaum describe how modern collaborative "peer production" online can be wildly productive. ${ }^{42}$ But what is true is that the interaction of the market with such nonmarket systems is a recipe for economic exploitation. ${ }^{43}$

A large part of the problem is that multiple studies show most users do not even understand that their private data shared with online companies like Google are being shared with third parties to assist in marketing advertising. ${ }^{44}$ This largely reflects that sharing

40. There is a rich anthropological tradition critiquing the reduction of nonmarket barter relationships to a simple market equivalence. Caroline Humphrey has written, "No example of a barter economy, pure and simple, has ever been described.” DAVID GRAeBER, DEbT: The First 5000 YeArs 29 (2011).

41. See Marcel Mauss, The Gift: Forms and Functions of Exchange in ARCHAIC SOCIETIES (Ian Cunnison trans., 1966).

42. SHIRKY, supra note 25, at 78-82; see also Benkler \& Nissenbaum, supra note 34 , at 402 .

43. Karl Polanyi has been one of the foremost documenters of the historical disruptions where market and nonmarket systems have collided. See KARL POLANYI, The Great Transformation (1944); Karl Polanyi, Trade and Market in the EARly EMPIRES: ECONOMIES IN History AND Theory (Karl Polanyi et al. eds., 1957); see also Paul Bohannan, The Impact of Money on an African Subsistence Economy, 19 J. ECON. HisT. 491, 491-503 (1959).

44. Ponnurangam Kumaraguru \& Lorrie Faith Cranor, Privacy Indexes: A SURVEY OF WeStiN's STUdies 13 (2005), available at http://reports-archive.adm.cs .cmu.edu/anon/isri2005/CMU-ISRI-05-138.pdf (finding about half of Americans believe that "most businesses handle the personal information they collect about consumers in a proper and confidential way"); Jan Whittington \& Chris Jay Hoofnagle, Social Networks and the Law: Unpacking Privacy's Price, 90 N.C. L. Rev. 1327, 1357 (2012) ("American consumers profoundly misunderstand the rules underlying these transactions; they do not understand the terms of trade."); 
the data is a default when signing up with a service, with little information shared with users to educate them about the consequences of sharing their data. The massive amount of data being shared online does not reflect public preferences: a 2012 Pew survey shows that seventy-three percent of the American public were opposed to search engines even tracking their search history to improve search results, and sixty-eight percent opposed use of user data to assist advertisers in targeting advertisements. ${ }^{45}$ But most of those users expressed no capacity to control what data is shared online. ${ }^{46}$ Other researchers found that desires to stop tracking, aggregating, and disseminating personal information have been increasing. ${ }^{47}$ Yet almost nowhere do defenders of Google factor in the costs to consumers of loss of privacy, yet as Peter Swire has noted, the nature of data aggregation is such that consumers with high privacy desires lose as data is concentrated in one company's hands. ${ }^{48}$

Notably, while dismissing the search bias antitrust claim against Google, Federal Trade Commissioner J. Thomas Rosch expressed concern that Google's "monopoly or near-monopoly power in the search advertising market" derives from Google "telling 'half-truths'-for example, that its gathering of information

see Alessandro Acquisti \& Jens Grossklags, What Can Behavioral Economics Teach Us About Privacy?, in Digital Privacy: Theory, Technologies And Practices 363, 363-64 (Alessandro Acquisti et al. eds., 2008) (stating that bounded rationality, optimism bias, and information asymmetry lead consumers to undervaluing personal information); Chris Jay Hoofnagle \& Jennifer King, Research Report: What Californians Understand About Privacy Offline 9-19 (May 15, 2008) (unpublished manuscript), available at http://papers.ssrn.com/sol3/papers.cfm ?abstract_id=1133075.

45. Kristen Purcell et al., Pew Research Ctr., Search Engine Use 2012, at 2 (2012), available at http://www.pewInternet.org/ /media/Files/Reports /2012/PIP_Search_Engine_Use_2012.pdf.

46. $\quad I d$. at 3 ("Just $38 \%$ of Internet users say they are generally aware of ways they themselves can limit how much information about them is collected by a website.").

47. Avi Goldfarb \& Catherine Tucker, Shifts in Privacy Concerns, 102 AM. ECON. REV. 349, 349 (2012) (explaining that millions of online decisions analyzed show a rising desire for privacy online).

48. Peter P. Swire, Submitted Testimony to the Federal Trade Commission for Behavioral Advertising Town Hall, EuR. PARLIAMENT 4 (Oct. 18, 2007), available at http:/ /www.europarl.europa.eu/meetdocs/2004_2009/documents/dv/testimony _peterswire_/Testimony_peterswire_en.pdf (written testimony of Peter Swire). 
about the characteristics of a consumer is done solely for the consumer's benefit, instead of also to maintain a monopoly or near-monopoly position." ${ }^{49}$ He cited precedent that a company's claims to be acting on behalf of consumers while downplaying potential consumer harms not fully disclosed could create legal liability. ${ }^{50}$

Google's barter for user privacy may be opaque and primitive, but that contrasts sharply with the way the company monetizes that personal data to advertisers who pay very precise dollar terms in the modern part of the Google economy. ${ }^{51}$ And those advertisers pay prices far above the costs spent by Google on the tools provided to users-as highlighted by Google's massive profits year after year. ${ }^{52}$ That advertising side of Google's internal economy is actually a monument to converting privacy into a modern currency, with sophisticated auctions for key words and phrases based on particular user demographics and backgrounds that the advertiser may be looking for. ${ }^{53}$ One analyst describes this has less to do with the sale of privacy itself by Google, but rather the sale of a "privacy derivative," where companies invest in Google's appraisal of customers' needs and wants. ${ }^{54}$

\section{Why Aren't Users Paid for Their Data?}

Some Google defenders ask, what could be better for consumers than getting all of Google's services free? This is part of

49. Rosch's Statement, supra note 7, at 1 n.1.

50. Id. (citing N. Am. Philips Corp., 111 F.T.C. 139, 188 (1988) (initial decision) (arguing that half-truths can be deceptive); Int'l Harvester Co., 104 F.T.C. 949, 1057 (1984) ("[I]t can be deceptive to tell only half the truth, and to omit the rest.")).

51. Hal Varian, How Auctions Set Ad Prices, Google Blog (May 12, 2008), http:/ / googleblog.blogspot.com/2008/05/how-auctions-set-ad-prices.html.

52. Google reported annual revenue of $\$ 50$ billion in 2012-a thirty-two percent increase from a year earlier-with annualized profits of over $\$ 14$ billion per year. Casey Newton, Google Revenue Hits $\$ 14.42 B$ in Fourth Quarter, Up 36 Percent, CNET (Jan. 22, 2013, 1:10 PM PST), http://news.cnet.com/8301-1023 _3-57565236-93/google-revenue-hits-\$14.42b-in-fourth-quarter-up-36-percent/.

53. Reach People Interested in Your Products or Services, GOOGLE SUPPORT, https://support.google.com/adwords/answer/2497941?hl=en (last visited Dec. 25, 2013); Varian, supra note 51.

54. Karl T. Muth, Googlestroika: Privatizing Privacy, 47 DuQ. L. REv. 337, 343 (2009). For further discussion on how Google monetizes user privacy, see $i d$. 
obscuring the economic value of personal data, much as early bank customers might not have expected more of banks than protecting their money in a vault for free until competitors began offering to pay them interest on that money deposited and offering rewards to customers using their credit cards. Economists regularly note that in two-sided markets where commercial interests, such as credit card companies, want a large base of users of a product, users on one side of the transaction are regularly paid to adopt the product. ${ }^{55}$ Just as banks leverage deposits to make money lending it out, Google makes money off of personal data deposited with them-yet a legal question is, why don't most Google users get a cut of the money Google makes off of their data?

Along with the general ignorance discussed above, Google thrives on the expectations of freely shared, online "peer production," which, as media professor Clay Shirky highlights, has a whole value system eschewing expectation of any precise quid pro quo exchange of value. ${ }^{56}$ Based on research that shows more voluntary activity when payment is not involved, ${ }^{57}$ Google's quasibarter relationship with its users may potentially be eliciting more free content and information from its users than if it actually paid them for it.

With all this, the first step in the transfer of wealth via Google is from users selling their privacy for too little and Google arbitraging user ignorance and their psychological mode of collaboration over market exchange for profit. This is the product of Google largely having the field to itself without serious competitive pressure to actually offer users the real value of their data. Competitors have tried to introduce models where users get a cut of the advertising revenue generated, ${ }^{58}$ but with Bing losing

55. See, e.g., Marc Rysman, The Economics of Two-Sided Markets, 23 J. Econ. PERSP. 125, 129 (2009).

56. See SHIRky, supra note 25, at 131-59. See generally Benkler \& Nissenbaum, supra note 34 , at 394 .

57. See Bruno S. Frey \& Lorenz Goette, Does Pay Motivate Volunteers? (Univ. of Zurich Inst. for Empirical Research in Econ., Working Paper No. 7, 1999), available at http://ideas.repec.org/s/zur/iewwpx.html (offering money depressed the number of hours of labor the average volunteer contributed).

58. Boaz Berkowitz, Cha-Ching: Microsoft Pays Users to Search with Bing, SEEkinG AlPHA (Aug. 10, 2009, 1:16 PM), http://seekingalpha.com/article/155148-cha -ching-microsoft-pays-users-to-search-with-bing; Robin Harris, Microsoft Stops Paying Us to Use Bing, ZDNET (June 6, 2010, 11:14 AM), http://www.zdnet.com/blog 
\$2.5 billion per year already, ${ }^{59}$ it's hardly surprising few companies have moved very far in the direction of further increasing their losses.

The result is that there is then little pressure on Google to offer anything to users out of its quite substantial profits from marketing user data to advertisers. Google did begin a small pilot program in 2012 called Google Search Screenwise that offers twenty-five dollars per year to a select set of people using the Chrome browser, although the numbers were limited and Google framed the plan not as a general reimbursement of users for using their data but merely a market research survey. ${ }^{60}$ So Google can dip its toe into paying a few users for even deeper revelations of their private activity while encouraging the vast majority of its users to continue thinking of participation in its services and sharing their data in nonmarket terms.

However, if Google had less dominance of the online advertising field, there would be far greater pressure for Google to develop as sophisticated a market for users to be compensated for their privacy as the precision of the markets in which it resells that lost privacy to advertisers. ${ }^{61}$

\section{Why USER DATA IS SO USEFUl TO ADVERTISERS: "PAIN POINTS" AND THE CONSUMER HARM OF PRICE DISCRIMINATION FACILITATED BY A MONOPOLY PLAYER LIKE GOOGLE}

Clearly, given Google's advertising profits, ${ }^{62}$ the user data the company collects is incredibly valuable and a number of analysts have put a price on what that data is worth for each individual user. For example, Michael Fertik, CEO of the company Reputation.com, a service to help consumers keep their personal information anonymous online, estimates that data can be worth up to $\$ 5000$ per person per year to advertisers, depending on how

\footnotetext{
/storage/microsoft-stops-paying-us-to-use-bing/960.

59. Robert Cyran, Microsoft Ought to Kick off Search for Bing Buyer, ReuTERS (July 22, 2011, 4:01 PM), available at Westlaw.

60. Jeff Bertolucci, Google Search's Screenwise vs. Bing Rewards: Which Pays More?, PCWORLD (Feb 9, 2012, 2:27 PM), http://www.pcworld.com/article /249683/google_searchs_screenwise_vs_bing_rewards_which_pays_more_html.

61. See Rysman, supra note 55, at 131 (noting how competition in credit card payment systems has increased rewards payment to consumers).

62. See Newton, supra note 52.
} 
much those users spend and how the data is used by online companies like Google. ${ }^{63}$ McKinsey has estimated that data mining broadly can increase operating margins by sixty percent for companies. $^{64}$

To get some sense of the value of user information, look at the recent controversy over another big Internet player, namely Apple, when it demanded that sellers of subscriptions to apps on the iPhone give them not just thirty percent of sales, but sole control of user information as well. ${ }^{65}$ Analyst Lauren Idvik noted that publishers like the Financial Times may not have liked the thirty percent cut Apple wanted from subscriptions, but "the main problem is that Apple will not share subscriber data with publishers, long one of publishers' most valuable assets, particularly to advertisers." ${ }^{.66}$ That the personal data, not the thirty percent cut, was the real sticking point in negotiations indicates that personal information is worth potentially more than thirty percent of the cost of what you purchase online, yet most users give it away for free to companies like Google and Apple.

As discussed further in the remedies section, any governmental action that strengthens user privacy rights, such as requiring an opt-in agreement for each specific use of their data by anyone collecting the information, would both reduce the amount of personal data being extracted and create a potential "friction" point where Google and other related data miners might feel compelled to pay users at least part of what that data is worth to convince them to share their private data, as well as guarantee better security for that data.

63. Quentin Fottrell, Who Would Pay $\$ 5,000$ to Use Google? (You), Market WATCH (Jan. 25, 2012, 12:24 PM), http://blogs.smartmoney.com/advice/2012/01 /25/who-would-pay-5000-to-use-google-you/ (“'Their entire market cap is related to how much data is being collected and used,' says Jules Polonetsky, director of the Future of Privacy Forum, a Washington, D.C.-based think-tank.").

64. James Manyika et al., McKinsey Global Inst., Big Data: The NeXt Frontier FOr InNOvation, COMPetition, AND Productivity 2 (2011), available at http://www.mckinsey.com/insights/business_technology/big_data _the_next_frontier_for_innovation.

65. Lauren Indvik, Financial Times Refuses to Give up Subscriber Data to Apple, MASHABLE (Apr. 4, 2011), http://mashable.com/2011/04/04/financial-times -subscriptions-apple/.

66. Id. 
That initial loss by users of giving their private information away too cheaply is just the start of the consumer harm from Google's dominance of the online advertising marketplace and its control of user data. The deeper potential harm, as will be discussed below, stems from the reason companies pay Google such a premium for that data in serving up advertisements to them based on that personal information.

The most positive spin on this use of user data for targeting ads is that it helps those companies find the customers interested in their products-and that's part of the story. But it's not just finding customers; it's finding out what price different groups of customers will pay for the same product or service and marketing it separately to them at those different prices.

The darker version of online marketing is that it can facilitate what economists call "price discrimination," selling the same exact good at a variety of prices, ${ }^{67}$ often in ways unknown to the buyers. This is based on the reality that people have different maximum prices that they are willing to pay, a so-called "pain point" after which they won't buy the product. ${ }^{68}$ The ideal for a seller would be to sell a product to each customer at their individual "pain point" price without them knowing that any other deal is available. In general, economists believe that where consumers do know all the pricing options, they can potentially benefit from price discrimination. $^{69}$ The classic example is airline pricing, where consumers willing to book ahead and take only certain flights get a lower price, while more well-off or time-sensitive consumers will pay

67. Price Discrimination, MERRIAM-WEBSTER, http://www.merriam-webster.com /dictionary/price\%20discrimination (last visited Jan. 30, 2014) ("the offering of similar or identical goods at different prices to different buyers").

68. IAN Ayres, Super Crunchers: Why Thinking-By-Numbers Is the New WAY TO BE SMART 190 (2007) (analyzing ways firms use data mining to set individualized coupon discounts even at traditional stores and noting "[firms] are becoming more adept at figuring out how much pricing pain individual consumers are willing to endure and still come back for more").

69. For a general survey of the literature, see William W. Fisher III \& Talha Syed, Infection: The Health Crisis in the Developing World ANd What We Should Do About It (forthcoming) (manuscript at ch. 6), available at https://cyber.law.harvard.edu/people/tfisher/Infection.htm (“[P]rice discrimination almost always benefits manufacturers. Sometimes it also benefits society at large; sometimes not.”). See generally Hal Varian, Price Discrimination and Social Welfare, 75 Am. ECON. REV. 870 (1985). 
more for the same seat to book at the last minute for a specific flight. This arguably fills seats, increases revenues for the airline, and gives some people access to cheaper seats that might not be available at all at the lower price without price discrimination. ${ }^{70}$

The problem arises when consumers don't have all needed information. As economist Joseph Stiglitz describes, "the presence of information imperfections give rise to market power in product markets. Firms can exploit this market power through 'sales' and other ways of differentiating among individuals who have different search costs." ${ }^{, 71}$

With public advertising, a customer willing to pay a higher price will generally demand the lower price advertised to someone else, although they may not notice the alternative ad, creating some imperfections in the marketplace. However, data mining and targeted Internet advertising allows sellers to make different advertising offers to particular groups of consumers based on correlations derived from past behavior or user location that are essentially invisible to anyone charged a higher price or missing out on a coupon. A 2012 Wall Street Journal report found that major companies, including Staples, Home Depot, Discover Financial Services, and Rosetta Stone, were systematically using information on user physical locations to display different online prices to different customers. ${ }^{72}$ And contrary to the hope that such price discrimination might benefit low-income bargain hunters, the Wall Street Journal found that "areas that tended to see the discounted prices had a higher average income than areas that tended to see higher prices," largely on the assumption that poor areas have

70. John Lazarev, The Welfare Effects of Intertemporal Price Discrimination: An Empirical Analysis of Airline Pricing in U.S. Monopoly Markets 4-5 (Jan. 7, 2013) (unpublished manuscript), available at https://files.nyu.edu/j15214/public /Lazarev_JMP.pdf.

71. Stiglitz, supra note 13, at 470; see also Salop, supra note 17, at 393-406; Steven Salop \& Joseph Stiglitz, Bargains and Ripoffs: A Model of Monopolistically Competitive Price Dispersion, 44 Rev. ECON. Stud. 493 (1977), reprinted in 1 THE ECONOMiCS OF INFORMATION 198 (David K Levine \& Steven A. Lippmann eds., 1995); Joseph E. Stiglitz, Monopoly, Non-Linear Pricing and Imperfect Information: The Insurance Market, 44 REv. ECON. STUD. 407, 407-30 (1977).

72. Jennifer Valentino-Devries et al., Websites Vary Prices, Deals Based on Users' Information, WALL ST. J., Dec. 24, 2012, at A1, available at LEXIS. 
fewer retail options locally so a higher price can be extracted from them by online retailers. ${ }^{73}$

In the case of search advertising, the New York Times in 2010 profiled how web coupons are deployed to target offers based on user behavior, including with different coupon offers being made based on different search terms on Google. As Ed Mierzwinski, consumer program director for the United States Public Interest Research Group (USPIRG) noted in a New York Times interview, companies "offer you, perhaps, less desirable products than they offer me, or offer you the same product as they offer me but at a higher price." ${ }^{, 74}$ USPIRG has asked the Federal Trade Commission for tighter rules on all online advertising precisely because of this problem. ${ }^{75}$ In his book Super Crunchers, Ian Ayers describes how data mining and selective discount offers to individuals is making prices increasingly opaque to consumers. ${ }^{76}$ Offering only full-price offers to some online buyers while selectively offering discounts to others based on online profiling is one of the most pervasive forms of price discrimination operating in online sales. $^{77}$

Despite hopes that online commerce would create greater consumer empowerment to engage in price comparisons, such hidden price discrimination frustrates that hope and adds to the shifting of power in overall online bargaining to sellers. Firms have also invested in a range of online strategies, from mandatory addons to multiple versions of a product to deliberately complicated descriptions designed to frustrate simple price comparisons between sites. Glenn and Sara Fisher Ellison have detailed these "price obfuscation" strategies and found they can regularly lead to far higher markups, even for commodity technology goods like memory modules, than would be expected in a more frictionless

73. Id.

74. Stephanie Clifford, Coupons from Internet Know a Lot About You, and They Tell, N.Y. TIMES, Apr. 17, 2010, at A1, available at 2010 WLNR 7964510.

75. Id.

76. AYERS, supra note 68, at 190 ("[Retail stores] can print out tailored coupons with prices just for you. . . . In a world of Super Crunching, it's going to be a lot harder to rely on other consumers to keep your price in line.").

77. Natasha Singer, You for Sale: Mapping, and Sharing, the Consumer Genome, N.Y. Times (June 17, 2012), 2012 WLNR 12625198 ("Acxiom . . . assigns consumers to one of 70 detailed socioeconomic clusters and markets to them accordingly. . . [with sellers making] customized appeals anytime, anywhere."). 
market. For example, where the Ellisons argue a markup of three percent to six percent would be expected for commodity products like memory modules, they found markups of twelve percent on average. $^{78}$

This all undercuts any model of online commerce that resembles the neoclassical ideal of a single equilibrium price for goods. Instead it far more reflects the information economics model of high search costs and variations in consumer rationality being used by firms to create a dispersion of prices. This allows firms to evaluate those search costs for different consumers and set prices in ways that extract the maximum revenue from each transaction. ${ }^{79} \mathrm{~A}$ key point from evaluating consumer welfare is that despite any advertised "bargains" or sales, overall prices in such a regime of obscured prices and seller price discrimination end up higher than any model of competitive prices where all price information was openly known and advertised. ${ }^{80}$ Where such price dispersion and obscured information exists, firms have a quasimonopolistic power to set prices which, as Steven Salop and Joseph Stiglitz outline, "they would be unable to do in a competitive market with perfect [price] information."

\section{The Economics of Price Discrimination in Google's Business Plan}

The question is how central facilitating such price discrimination is to Google's business model. Given that Google appointed Hal Varian, who has written extensively about price discrimination in online advertising for decades, ${ }^{82}$ to be the company's Chief Economist in 2005, the answer seems to be that it's likely quite central to their model.

That same year, Varian outlined the advantages to advertisers of online marketing and price discrimination in a piece he coauthored for the journal Marketing Science that echoed many of

78. Glenn Ellison \& Sara Fisher Ellison, Search, Obfuscation, and Price Elasticities on the Internet, 77 ECONOMETRICA 427, 427-29 (2009) ("Obfuscation can be thought of as an action that raises search costs, which can lead to less consumer learning and higher profits.”).

79. Salop \& Stiglitz, supra note 71, at 493-96.

80. Id. at 502 .

81. Id. at 509 .

82. Hal Varian's writing on price discrimination dates back at least to 1980 in his paper, Hal R. Varian, A Theory of Sales, 70 AM. ECON. REV. 651 (1980). 
the basic insights of information economics in the context of online sales. ${ }^{83}$ Varian, Google's Chief Economist, highlights the failure of most price discrimination to yield profits in traditional marketing because of the visibility of different prices to most customers, but that "significant initial investments in information technology can lead to competitive advantages" that lock in user loyalty while collecting personal information to make price discrimination profitable. ${ }^{84}$ As he describes:

Because so many transactions are now computer mediated, and these computers can easily be networked to data centers, sellers now have the ability to access databases of past purchases in real time. This allows them to condition current offers to consumers on their previous purchase behavior. Sellers can offer each individual a different price, a particular prize or coupon, or personalized recommendations. With computer-mediated transactions, price discrimination on an individual basis becomes quite feasible.

Varian notes that differential pricing will be most effective on the "fraction of the potential population [that] is myopic and ignores the impact of their current behavior on future offerings" and how undermining the ability of users to make their behavior anonymous increases the costs to users of evading price discriminationa point he hits repeatedly in the piece and a good explanation of Google's focus on obliterating anonymous browsing online. ${ }^{86}$

By locking users in to particular services, building loyalty (or just making it a chore to $\log$ in or out of the online service), and designing a "selling platform with the goal of making the adoption of defensive technologies prohibitively costly for the consumer," companies will increase their profits at the expense of their customers, particularly the "myopic" ones, even under competitive markets.

While Varian's example in 2005 was clearly about Amazon, the measures he focused on-user lock-in, integrated user profiles,

83. Alessandro Acquisti \& Hal R. Varian, Conditioning Prices on Purchase History, 24 MARKETING SCI. 367 (2005).

84. Id. at 380 .

85. Id. at 367 .

86. Id. at 380 .

87. Id. at 374 . 
defeating anonymity-describe exactly the systematic deployment of products and systems Google has pursued as well. As early as 2004, Google was applying for patents on how to sell advertising based on such behavioral and demographic tracking, where one patent specified, "advertisements are personalized in response to a search profile that is derived from personalized search results." Since 2009, Google has been rolling out beta tests of such behavioral profiling for advertisers and in 2011 fully implemented its coordination of advertising with targeting demographic groups identified by Google based on user browsing activity, behavior, and physical location. ${ }^{89}$ So companies working with Google can more and more effectively segment the market by demographic profiles yielding the "myopic" customers who will pay the maximum price based on their demographic and behavioral characteristics. ${ }^{90}$

Varian's analysis focuses on a number of scenarios where sellers use price discrimination to increase overall sales. In many, any overall economic value added in the economy "is entirely due to the increased profit received by the seller," ${ }^{, 1}$ while in a number of other scenarios outlined by Varian, consumer welfare as a whole actually falls. Even if economic efficiency overall strengthened in some scenarios, the fact that those gains include a large loss for some or, in many cases, all consumers to the advantage of sellers emphasizes that the argument that technology increases overall "consumer welfare" means little if all of the increased economic growth goes only to sellers at the expense of actual consumers. Courts and many scholarly analysts have emphasized that the

88. U.S. Patent Application No. 10/877775 (filed June 24, 2004), available at http://appft1.uspto.gov/netahtml/PTO/search-adv.html (search for “20050222989”).

89. Pamela Parker, Google Rolls Out Behavioral Targeting to All AdWords Advertisers, SEARCH ENGINE LAND (June 23, 2011, 6:09 PM), http://searchengine land.com/google-rolls-out-behavioral-targeting-to-all-adwords-advertisers- 82976 .

90. See Ahmadali Arabshahi, Google's Groupon Strategy: Algorithmic PriceSensitivity Quotients, AHMADALI's Blog (Jan. 17, 2011), http://www.ahmadalia.com /blog/2011/01/google-groupon-strategy.html (detailing how such behavioral tracking can work for Google in creating a profile for advertisers that helps identify price-sensitive versus price-insensitive customers). Arabshahi sees Google's launch into Groupon-like offers working with local businesses as a way for Google to better monetize its data on its users. Id.

91. Acquisti \& Varian, supra note 83 , at 372. 
Sherman $\mathrm{Act}^{92}$ is not an economic efficiency maximization statute and that productivity gains from monopoly-maintaining innovations that benefit sellers at the expense of consumers still constitute a violation of antitrust law.

Rosa-Branca Esteves and Joana Resende in more recent research highlight the ways that, because of the low costs of online advertising, ${ }^{4}$ such online price discrimination can reduce consumer surplus to the advantage of corporate profits. ${ }^{95}$ They emphasize that models of price discrimination that benefit consumers are based on the assumption that consumers are perfectly informed of all available prices, but with imperfect consumer information and targeted advertising, models shift towards price discrimination benefiting company profits at the expense of consumers. ${ }^{96}$ One implication of their models is that "average prices with mass advertising (nondiscrimination) are below those with targeted advertising," which follows the idea that firms will target certain consumers with promotions while enjoying higher prices paid by Varian's "myopic" consumers unaware of discounts offered to others. ${ }^{97}$

92. $\quad 15$ U.S.C. $\$ \S 1-7$ (2012).

93. See, e.g., Weyerhaeuser Co. v. Ross-Simmons Hardwood Lumber Co., 549 U.S. 312, 323 (2007); Brooke Grp. Ltd. v. Brown \& Williamson Tobacco Corp., 509 U.S. 209, 224 (1993); Jefferson Parish Hosp. Dist. No. 2 v. Hyde, 466 U.S. 2, 15 (1984), abrogated by Ill. Tool Works Inc. v. Indep. Ink, Inc., 547 U.S. 28 (2006); Reiter v. Sonotone Corp., 442 U.S. 330, 343 (1979); Einer Elhauge, Tying, Bundled Discounts, and the Death of the Single Monopoly Profit Theory, 123 HARv. L. REv. 397, 435-36 (2009) (citing NCAA v. Bd. of Regents of Univ. of Okla., 468 U.S. 85, 107 (1984)).

94. See generally Esteves \& Resende, supra note 17. Esteves and Resende contrast their results when low advertising costs are assumed with disputed studies over whether, in cases of more costly conventional advertising, targeted advertising increases profits. Id. Compare Nada Ben Elhadj-Ben Brahim et al., Is Targeted Advertising Always Beneficial?, 29 INT'L J. INDus. ORG. 678, 685 (2011) ("When the advertising cost is high, targeting reduces firms' profits relative to random advertising."), with Ganesh Iyer et al., The Targeting of Advertising, 24 MARKETING SCI. 461, 461 (2005) ("[T]he targeting of advertising increases equilibrium profits.").

95. Esteves \& Resende, supra note 18, at 1 (“[P]rice discrimination through targeted advertising may be detrimental to social welfare since it boosts industry profits at the expense of consumer surplus.").

96. Id. at 6-7.

97. Id. at 28 . 


\section{The CASE FOR Legal ACTION ON CONSUMER HARM From Price DISCRIMINATION}

With so much of seller profit from price discrimination online derived from exploitation of "myopic" customers failing to know about or find cheaper alternatives to the prices offered them, ${ }^{98}$ a number of antitrust theorists who focus on allocative efficiency argue price discrimination is one category of consumer harm that demands legal action.

In his article Unconscionability and Price Discrimination, ${ }^{99}$ Mark Klock, while accepting most traditional Chicago School skepticism of government regulation in the marketplace, argues that any situation where one set of consumers is unknowingly paying more for the same product than others is a clear sign of a failure in the marketplace that calls for government intervention. He is skeptical of hypothetical cases of consumer gain from price discrimination ${ }^{100}$ and argues, "[a] sound policy would prohibit firms from charging different prices based solely on the identity of the customer." Echoing the studies discussed above, Klock and others argue such price discrimination established under the aegis of a monopolist in the marketplace is even more harmful to consumer welfare. ${ }^{102}$ Douglas M. Kochelek has also highlighted that the rise of data mining online has made the problem of price discrimination far more pervasive in the economy, raising the importance of deploying antitrust as a curb on dominant players using it. ${ }^{103}$

Given that Google's control of user data to facilitate price discrimination is based at least partially on tying so many services that extract that data into its core search advertising product, it's worth emphasizing that the Supreme Court has condemned traditional tying in many cases because it allowed companies to

98. Acquisti \& Varian, supra note 83, at 380.

99. Mark Klock, Unconscionability and Price Discrimination, 69 TENN. L. REv. 317 (2002).

100. See id. at 358 (dismissing the "empirically unsubstantiated case in which price discrimination achieves allocative efficiency").

101. Id. at 367 .

102. Id. at 329 ("Economists consider the price-discriminating monopolist to be very undesirable."); Douglas M. Kochelek, Note, Data Mining and Antitrust, 22 HARV. J.L. \& TECH. 515, 531 (2009) (“[D]ata mining technologies are able to facilitate price discrimination within a monopoly market.").

103. Kochelek, supra note 102, at 521. 
identify different classes of consumers and, as stated in Jefferson Parish Hospital District No. 2 v. Hyde, use that power "to impair competition . . . by facilitating price discrimination, thereby increasing monopoly profits over what they would be absent the tie." 104

What's unique about Google is that it can use its monopoly power not just to engage in price discrimination directly in regards to its advertising customers and potentially with users in its own e-commerce efforts, but also as a vehicle for companies across the economy to engage in such consumer harm via price discrimination, which should raise the priority for restraining its power in the marketplace. While firms would no doubt be taking advantage of targeted advertising to engage in price discrimination whatever the competitive nature of the search advertising industry, the lack of competition in the sector feeds the monopoly ability of Google to extract user data. A more developed market where users are more able to refuse to share their data combined with a more fractured set of players in the sector where no one player like Google would have so much data about all users would weaken the ability of advertisers to engage in price discrimination.

Both Klock and Kochelek argue that, in the ideal, the explicit antitrust language in the Robinson-Patman $\mathrm{Act}^{105}$ on price discrimination should be a tool to address the problem. ${ }^{106}$ While the Robinson-Patman Act arguably does not address the harm of price discrimination to primary consumers, ${ }^{107}$ it does potentially

104. 466 U.S. 2, 14-15 (1984), abrogated by Ill. Tool Works, Inc. v. Indep. Ink, Inc., 547 U.S. 28, 31 (2006). For a general analysis of this line of cases, noting that courts disfavor the way tying facilitates price discrimination, see Elhauge, supra note 93, at 421-26. See also United States v. Loew's, Inc., 371 U.S. 38 (1962), abrogated by Ill. Tool Works, 547 U.S. at 31; N. Pac. Ry. Co. v. United States, 356 U.S. 1 (1958), superseded by statute, 35 U.S.C. $\$ 271$ (d) (4)-(5) (2006); United Shoe Mach. Corp. v. United States, 347 U.S. 521 (1954); Int'l Salt Co. v. United States, 332 U.S. 392 (1947), abrogated by Ill. Tool Works, 547 U.S. at 31-33.

105. 15 U.S.C. $§ 13$ (2012).

106. Klock, supra note 99, at 383 ("The treble damage framework of the Robinson-Patman Act with application to services and consumers would be a good start."); Kochelek, supra note 102, at 524. Both Klock, supra note 99, at 330, and Kochelek, supra note 102, at 526, have doubts, however, that courts will accept their arguments.

107. See Frederick M. Rowe, Price Discrimination Under the RobinsonPATMAn ACt 173 (1962) (arguing Robinson-Patman does not apply to consumer 
address situations where the ability, which Google has, to facilitate price discrimination is a primary attribute strengthening its monopoly power vis-à-vis competitors. ${ }^{108}$ In any case, more general antitrust enforcement under the Sherman Act should be sufficient in cases of monopoly players wielding price discrimination and imposing the dead weight losses for consumer welfare discussed above. $^{109}$

\section{Subprime Mortgages, "Ambulance Chasers AND SNAKe OIL SALESPEOPLE”: HOW ONLINE ADVERTISING UNLEASHES THE "TAWDRY" SIDE OF CAPITALISM}

How widespread the use of price discrimination and behavioral marketing is among legitimate businesses using Google to increase their profits at the expense of consumers is largely a matter for investigation by federal agencies, since Google quite obviously keeps such data closely held. There is of course wideranging use of selectively offered promotions on websites throughout e-commerce promoted through Google search and display advertising, so that basic form of price discrimination is clearly in place. Evaluating the broad ways consumers are harmed by such selective price discrimination, a harm that even Google's own Chief Economist admits is far more than a theoretical

transactions). Kochelek largely dismisses the likelihood of using Robinson-Patman for this reason. Kochelek, supra note 102, at 525-26 ("Accordingly, the practice likely cannot be regulated under the primary-line theory of the Robinson-Patman Act.”).

108. While Klock agrees that case law makes him skeptical of using RobinsonPatman, he argues agencies and courts might broaden their interpretation of Robinson-Patman in light of the expansion of price discrimination in the marketplace. Klock, supra note 99, at 379. However, neither of the authors consider a case such as Google where the ability to engage in price discrimination is largely the basis of undermining the ability of competitors to enter the same market, so Robinson-Patman might be more applicable in this case.

109. Kochelek, supra note 102, at 526 ("Regardless of the particular theory of the purpose of antitrust regulation one accepts, the economic effects of datamining-based price discrimination suggest that such conduct ought to be proscribed by the Sherman Act.”). However, Klock in particular thinks the potential enforcement threat of direct class action lawsuits by consumers wielding Robinson-Patman is a potentially better deterrence than depending on agency or competitor lawsuits against price discrimination under the Sherman Act. See Klock, supra note 99 , at $377-78$. 
possibility, ${ }^{110}$ should be a primary focus for antitrust investigations into Google.

However, while Google's facilitation of price discrimination can increase profits for all businesses, targeted advertising has maximum appeal to the unethical and even illegal businesses seeking to prey on such "myopic" consumers that Google can help them identify. Early Internet visionary Jaron Lanier, who pioneered ideas like "virtual reality" two decades ago, has noted that such access to behavioral targeting has even more appeal to the "tawdry" kinds of firms than the "dignified side of capitalism," since "ambulance chasers ... and snake oil salespeople" among the capitalist class thrive on such targeted access to their victims. ${ }^{111}$ Lanier argues that:

Google's thing is not advertising . . . . It's a link. It's just a little tiny minimalist link . . . . What they're doing is they're saying, "You give us money, we give you access to these people, and then what you do with them is up to you." It's a gate keeping function. It's an arbiter of access. It's turning connections instead of being open into being paid. $^{112}$

This also emphasizes that Google's version of advertising is distinct in its function from other traditional advertising.

\section{A. Racial and Economic Profiling Online}

Study ${ }^{113}$ after study ${ }^{114}$ has shown that employers, financial lenders, car salesmen, and other merchants use profiling to charge black and Hispanic customers more for the same product or service when they can identify them. For example, a study by the Urban Institute using paired "testers"-one white person and one person of color with similar economic profiles-found that nonwhite

110. See Acquisti \& Varian, supra note 83, at 373.

111. Brockman, supra note 11.

112. Id.

113. Margery Austin Turner et al., U.S. Dep't of Hous. \& Urban Dev., All Other Things Being Equal: A Paired Testing Study of Mortgage Lending InSTITUTIONS (2002), available at http://www.urban.org/UploadedPDF/1000504 _All_Other_Things_Being_Equal.pdf.

114. Marianne Bertrand \& Sendhil Mullainathan, Are Emily and Greg More Employable Than Lakisha and Jamal? A Field Experiment on Labor Market Discrimination, 94 AM. ECON. REv. 991 (2004). 
homebuyers received less favorable financial terms from mortgage lending institutions. ${ }^{115}$ Job seekers face similar discrimination. One study, where nearly identical resumes were sent to 1300 help wanted ads, found that resumes with a "white-sounding" name were fifty percent more likely to get a call for an interview than one with a "black-sounding" name. ${ }^{116}$ Just in 2012, the U.S. Department of Justice negotiated a $\$ 175$ million settlement with Wells Fargo for illegally steering more than 30,000 black and Hispanic borrowers between 2004 and 2009 into more costly subprime mortgages or charging them higher fees than comparable white borrowers.

Online behavioral targeting can combine a home address and a few more characteristics to create an almost perfect proxy for race. Rebecca Goldin, a George Mason University professor, argued in a 2009 article that while it's clearly illegal to discriminate based on race, if companies offer loan rates based on shopping habits, it raises the question, "[w] ould it be legal or ethical to use the kind of music one buys to determine his or her loan rate . . . ?"118 The Supreme Court has essentially invited such data-driven discrimination by prohibiting explicit race preferences or discrimination but allowing disparate impact along racial lines as long as decisions were made based on "race-neutral" criteria. ${ }^{119}$

115. TURNER ET AL., supra note 113, at 1.

116. Bertrand \& Mullainathan, supra note 114, at 991.

117. James O’Toole, Wells Fargo in $\$ 175$ M Discriminatory Lending Settlement, CNN MONEY (July 12, 2012, 1:12 PM), available at LEXIS (stating that a typical African-American borrower paid nearly $\$ 3000$ more in fees than a similarly qualified white applicant). In an echo of the search for "myopic" customers promoted by Google's Varian, in a subprime-mortgage-related lawsuit, Washington Mutual loan officer Greg Saffer related in a legal filing that trainers at his bank instructed loan officers to target subprime loans to poor areas and that the "best areas to market are in lower income areas like Compton and Long Beach because the people are less sophisticated there." Confessions of an Economic Hate Crime, DAS KRAPITAL (July 30, 2012), http://www.daskrap.com/2012/7/confessions-economic -hate-crime.

118. Rebecca Goldin, Doting on Data, 56 Notices Am. Mathematical Soc'y 483, 486 (2009), available at http://www.ams.org/notices/200904/rtx090400483p .pdf (reviewing AYRES, supra note 68).

119. Justice O’Connor argued for "race-neutral means to increase minority business participation" in City of Richmond v. J.A. Croson Co., 488 U.S. 469, 507 (1989). See also Owens v. Nationwide Mut. Ins. Co., No. 3:03-CV-1184-H, 2005 WL 1837959, at*14-15 (N.D. Tex. Aug. 2, 2005) (stating even if credit scores have disparate impact on minorities, race-neutral business reasons for credit scores 
As Colorlines has noted, "a user's browsing history, their location and IP information . . . combined with information available in Google's public data explorer (including [U.S.] census, education, population, STD stats, and state financial data) presumably could also be folded into the personalized search algorithm to surmise a lot more than your race." ${ }^{20}$ While not conclusive, there is evidence of companies using names or other evidence such as physical location to offer differential advertising through Google based on race and ethnicity. ${ }^{121}$

\section{B. Google and the Subprime Mortgage Crisis}

What is unquestionable is that Google advertising lay at the heart of the largest example of price discrimination and consumer harm of the last few decades, namely the subprime mortgage destruction of family wealth and the financial crisis that followed.

Google isn't usually identified as a big player in the subprime mortgage debacle and its aftermath, but a significant portion of Google's profits in the mid-2000s were coming straight from subprime mortgage lenders advertising on its site. As Jeff Chester of the Center for Digital Democracy said back in 2007, "[m]any online companies depend for a disproportionate amount of their income on financial services advertising, with subprime in some cases accounting for a large part of it." ${ }^{122}$ To give some sense of its

allow their use); Powell v. Am. Gen. Fin., Inc., 310 F. Supp. 2d 481, 488 (N.D.N.Y. 2004) (stating that nonsubjective credit indicators that have disparate impact on minorities are permissible).

120. Jorge Rivas, Google Calls Racial Profiling Claims 'Wildly Inaccurate', ColOrLines (Sept. 28, 2011, 10:10 AM), http://colorlines.com/archives/2011 /09/google_responds_to_preliminary_study_says_their_ads_dont_racially_profile .html.

121. See Latanya Sweeney, Discrimination in Online Ad Delivery, 56 Comm. Ass'N COMPUTING MACHINERY 44, 44 (2013) (finding ads associate term "arrested" with black-sounding names more than with white-sounding names); Nathan Newman, Racial and Economic Profiling in Google Ads: A Preliminary Investigation (Updated), Huffington Post (Sept. 20, 2011, 3:17 PM), http://www.huffingtonpost.com /nathan-newman/racial-and-economic-profi_b_970451.html (discussing a survey that found examples of different ads being served up based on the ethnicity of names and location of the computer).

122. Jeff Chester, Role of Interactive Advertising and the Subprime Scandal: Another Wake-up Call for FTC, Digital Destiny (Aug. 28, 2007, 11:00 AM), http://www .democraticmedia.org/jcblog/?p=349. 
importance, Nielsen//Netratings released research in July 2007 of the online display advertisers spending the most money. ${ }^{123}$ The top five online advertisers were involved in the mortgage lending industry to some extent, delivering almost $\$ 200$ million in monthly revenue to online advertising companies like Google, with literally over a hundred billion views of those online ads driving the frenzy for refinancing and subprime mortgages with ads like "LowerMyBills" and other online enticements.

Those numbers above are for display ads only, a segment in which Google was and is a prime player through its Doubleclick purchase. Google does not share data on specific revenue from particular companies on its AdWords and related search advertising, but reports at the time showed the mortgage companies paying top dollar for related keywords like "mortgage" and "refinance," with prices going as high as twenty to thirty dollars for each user that clicked on an ad using those terms. ${ }^{125}$

Companies enticed customers with unrealistic "teaser rates"heavily advertised online-that burdened borrowers with toxic terms and unmanageable obligations that exploded in later years. ${ }^{126}$ And the racial and exploitive aspect of the mortgage meltdown was endemic with what some scholars described as reverse redlining, "the practice of targeting borrowers of color for loans on unfavorable terms." This offering of differential rates based on the characteristics of the borrower constitutes the most damaging price discrimination inflicting consumer harm in American history, ${ }^{128}$ for which Google played an integral (and profitable) role

123. Press Release, Nielsen//NetRatings, Nielsen//NetRatings Reports Topline U.S. Data for July 2007 (Aug. 13, 2007), http://www.nielsen-online .com/pr/pr_070813.pdf.

124. Id.

125. Faisal Laljee, Subprime Mortgage Bust Could Create Ad Trouble for Google, SEEkING AlPHA (Feb. 22, 2007, 4:04 AM), http://seekingalpha.com/article/27736 -subprime-mortgage-bust-could-create-ad-trouble-for-google.

126. See Chester, supra note 122.

127. Raymond H. Brescia, Subprime Communities: Reverse Redlining, the Fair Housing Act and Emerging Issues in Litigation Regarding the Subprime Mortgage Crisis, 2 Alb. Gov'T L. Rev. 164, 167 (2009).

128. See Michelle Singletary, King's Dream Deferred, One More Victim of the Subprime Mortgage Crisis, WASH. POST, Feb. 10, 2008, at F01, available at LEXIS ("[T] he subprime mortgage crisis has caused the largest loss of wealth for black and Latino homeowners in modern U.S. history.”). 
as an advertising intermediary where it was earning billions of dollars a year.

\section{Google's Continued Role in Facilitating Financial Exploitation of Consumers}

The financial industry remains the bedrock of Google's advertising revenues. ${ }^{129}$ According to WordStream, a company specializing in helping companies bid effectively on Google Ads, the three most expensive categories of keyword searches as measured by cost per click are in financial services-insurance, loans, and mortgages-with $45.8 \%$ of the top 10,000 advertising keywords falling in those categories. ${ }^{130}$

And many of those advertising bidders at Google are from the more bottom-feeding aspects of the industry, particularly payday loan lenders, who offer extremely high-interest loans for consumers made in exchange for a commitment to repayment from the person's next paycheck. ${ }^{131}$ Such loans have been banned or severely restricted as exploitative in multiple states. ${ }^{132}$ The new Consumer Financial Protection Bureau (CFPB) has been holding hearings specifically on abuses in the industry, with CFPB head Richard Cordray saying that "some payday lenders [are] engaged in practices that present immediate risk to consumers and are clearly illegal."

Yet Google actively solicits ads from the industry, including setting up a trade booth at the Online Lenders Alliance, a trade group comprised mainly of payday lenders. ${ }^{134}$ Industry observers

129. Larry Kim, The Most Expensive Keywords in Google AdWords, WORDSTREAM (July 18, 2011), http://www.wordstream.com/blog/ws/2011/07/18 /most-expensive-google-adwords-keywords.

130. Id.

131. Robert X. Cringely, Google's Pound of Flesh, Cringely (Sept. 27, 2010), http://www.cringely.com/2010/09/27/googles-pound-of-flesh.

132. Payday Lending State Statutes, NAT'L Conf. St. Legislatures, http://www .ncsl.org/issues-research/banking/payday-lending-state-statutes.aspx (last updated Sept. 12, 2013).

133. Press Release, Richard Cordray, Dir., Consumer Fin. Prot. Bureau, Prepared Remarks at the Payday Loan Field Hearing in Birmingham, Ala., (Jan. 19, 2012), http://www.consumerfinance.gov/newsroom/remarks-by-richard -cordray-at-the-payday-loan-field-hearing-in-birmingham-al.

134. Cringely, supra note 131. 
like Robert X. Cringely, who has covered Silicon Valley for over twenty-five years, have cited this involvement as a step beyond passively accepting ads from dubious sources to actively enabling evil. He argues that out of financial self-interest, Google is burying bad news about the industry for consumers, since he found Google "placed the uniformly negative news items near the bottom of the results, below the fold as we used to say in the newspaper business." $" 135$

Whether, as Cringely argues, Google is actively hiding damning consumer analysis of the evils of its financial advertisers, what is true is that Google maintained ads from illegal mortgage "loan modification" firms preying on desperate homeowners even after the company was alerted to the problem. ${ }^{136}$ Such firms advertise heavily online with consumers looking for keywords such as "stop foreclosure," then promise solutions that never deliver and further impoverish those homeowners facing financial default. ${ }^{137}$ Back in February 2011, the consumer group Consumer Watchdog published a scathing report highlighting the concentration of such firms advertising on Google, ${ }^{138}$ but Google did nothing about the problem until the Treasury Department took regulatory action in November of that year under its TARP authority to shut down eighty-five of these scam advertisers who were luring customers through Google. ${ }^{139}$ "Many homeowners who fall prey to these scams, initially do so through these Web banners and other Web advertising,' Christy Romero, Deputy Special Inspector General for the Troubled Asset Relief Program, said in an interview." ${ }^{140}$

\footnotetext{
135. Id.

136. See Consumer Watchdog, Liars And LoAns: How Deceptive Advertisers UsE GOOGLE 5-7 (2011), available at http://www.consumerwatchdog.org /resources/liarsandloansplus021011.pdf.

137. Id.

138. Id.

139. Feds Shut Down High-Tech Mortgage Scammers, CBS News (Nov. 16, 2011, 3:30 PM), http://www.cbsnews.com/8301-205_162-57326180/feds-shut-down-high -tech-mortgage-scammers/.

140. Id.
} 


\section{Promoting Illegal Drug Advertisements Earned Google One of the Largest Civil Forfeitures in American History}

In a similar vein to Google's promotion of unethical and illegal financial advertisers, in August 2011, Google agreed to pay a $\$ 500$ million civil forfeiture to the federal government, one of the largest in history, as part of a settlement penalizing the company for illegally and-significantly-knowingly allowing illegal pharmacies to advertise on its site. ${ }^{141}$ This was not passive activity by Google, but active complicity with advertisers often selling fake prescription medicine to desperately ill individuals or marketing illegal steroids. "'[Google founder and CEO] Larry Page knew what was going on,' Peter Neronha, the Rhode Island U.S. Attorney who led the probe, told The Wall Street Journal." ${ }^{142}$

As early as 2003, Google was put on notice by the government that its advertisements for various foreign-based pharmacies were illegal, ${ }^{143}$ yet the company continued to assist many of them in placing and optimizing their AdWords advertisements. ${ }^{144}$ In fact, a follow-up story by the Wall Street Journal detailed how a felon, David Whitaker, who ended up collaborating with the federal government to target Google, had fled to Mexico and was advanced credit by Google and assisted by Google ad executives in designing ads to sell illegal steroids and similar products. ${ }^{145}$ Federal agents created a website designed to look "as if a Mexican drug lord had built a website to sell HGH and steroids" and Google ad executives worked with Mr. Whitaker to find ways around Google's official rules barring such ads. ${ }^{146}$ Whitaker went on to tape record conversations where he directly told Google ad executives that his goal was to be "the biggest steroid dealer in the United States." Disturbingly,

141. Thomas Catan \& Amir Efrati, New Heat for Google CEO: U.S. Says Google's Larry Page Knew About Improper Online Pharmacy Ads, WAll ST. J., Aug. 27, 2011, at $\mathrm{B} 1$, available at LEXIS.

142. Clint Boulton, Google's Page Knew of Illegal Pharmacy Ads: DOJ, EWEeK (Aug. 28, 2011), http://www.eweek.com/c/a/Search-Engines/Googles-Page-Knew -of-Illegal-Pharmacy-Ads-DOJ/.

143. Catan \& Efrati, supra note 141.

144. Thomas Catan, Con Artist Starred in Sting That Cost Google Millions, WaLL ST. J., Jan. 25, 2012, at A1, available at LEXIS.

145. Id.

146. Id.

147. Id. 
documentation about the individual culpability of Google executives was sealed as part of the settlement with prosecutors, which prevents other government officials from evaluating the evidence in light of broader antitrust and other regulatory concerns. ${ }^{148}$

\section{CONCLUSION: THE BROAD CONSUMER HARM FROM GOOGLE'S MONOPOLY IS NOT BEING CORRECTED BY MARKET MECHANISMS}

These examples are just the most obvious unethical and illegal categories of advertisers that have been highlighted due to government investigations. What is most worrying is that the nature of targeted advertising means that a whole range of niche scams and economically exploitive relationships can be focused on those most vulnerable to the scam's appeal, while remaining essentially invisible to everyone else, including reporters and researchers trying to evaluate the harms from Google's advertising methods.

As detailed above, there are broad reasons why consumers are not demanding a fair return from Google when trading their privacy in exchange for using Google's services. However, there are even more obvious market failures from these broader financial losses where consumers lack information on the operations of price discrimination and the danger of many of these predatory firms advertising online.

In measuring consumer harm, then, it is therefore the broad financial losses to consumer welfare facilitated by lost privacy and Google's data mining efforts, including the predatory behavioral targeting of users provided by Google based on its control of user data, that should be a prime focus for investigation by antitrust regulators and legislative leaders. Much of this is no doubt in the day-to-day price discrimination encouraged for businesses using online advertising, but a significant fraction is also from companies engaged in unethical to illegal activities facilitated by the company.

The fact that profitable price discrimination depends on a combination of user ignorance and service lock-in, according to Google's own Chief Economist Hal Varian, ${ }^{149}$ means the market

148. Boulton, supra note 142; see also Nathan Newman, Erosion of Public Scrutiny of Litigation-and Irony of Google Wanting Privacy for Its Judicial Dealings, TecHProgress (Feb. 18, 2011), http:/ /www.tech-progress.org/?p=101.

149. Acquisti \& Varian, supra note 83, at 380. 
alone cannot address that issue of equity and market power by Google. Similarly, markets have shown themselves incapable of policing the broader harms to society that stem from wide-scale harms such as the subprime mortgage crisis, which stemmed from combinations of consumer ignorance and price discrimination in mortgage offers. Public action is equally needed to police the "tawdry" side of capitalism, whose advertisers seem endemic on Google, from its fake "loan modification" scams to illegal pharmacies.

\section{A. Remedies to Address Consumer Harm from Lost Privacy Online}

Traditional antitrust enforcement would help accomplish some of these goals and I have described some antitrust remedies, including strengthening consumer control over their own data, as a way to limit the consumer harm from Google's monopoly. ${ }^{150}$ However, because of the complexity of implementing some of these remedies through agencies and the courts, some reforms might be implemented better through existing powers of the Federal Trade Commission and other agencies. Other measures may call for additional legislation to bring both antitrust and consumer protection laws more explicitly up-to-date to address the broad consumer harm and rising economic inequality stemming from data mining online.

In March 2012, the FTC issued a report, Protecting Consumer Privacy in an Era of Rapid Change, that sought to outline a framework for privacy protection for businesses to adopt voluntarily and, where necessary, policymakers to mandate as part of general consumer protection. ${ }^{151}$ The framework includes so-called "Do Not Track" rules for web browsers such as Google's Chrome browsers to ensure user activity can be hidden from advertisers, data portability to allow users to switch easily between email and social networking services and take their data with them, and greater transparency and choice by consumers on where and how they share their data with companies. ${ }^{152}$ There is good evidence from Europe that

150. Newman, supra note 8 (manuscript at 62-69).

151. Fed. Trade Comm'n, Protecting Consumer Privacy in an Era of Rapid Change: Recommendations for Businesses And Policymakers 72-73 (2012), available at http:/ / www.ftc.gov/os/2012/03/120326privacyreport.pdf.

152. See generally id. 
privacy regulation can in fact decrease behavioral tracking of users online.

The FTC framework also suggests companies should be required to obtain "express consent" when collecting "sensitive data," such as health and other data regulators might deem most subject to abuse. ${ }^{154}$ While one FTC commissioner questioned whether "opt-in" requirements would work for smaller companies, ${ }^{155}$ I would argue that in the case of Google, whether through regulation or as a specific antitrust remedy, a detailed and explicit "opt-in" consent should be required for any use of the data with specific express consent required for any change or new use of the data in the future. If users were reluctant to invest the time to complete the process of giving such consent, that would actually serve a positive purpose in encouraging Google to offer economic incentives for users to do so. By jumpstarting a real market for user data, not only would that reverse some of the economic distribution towards Google, it would open up more space for other companies to compete on incentives at that point of friction and thereby ease monopoly concerns. Limiting such an opt-in requirement for sharing data to Google and other similar large, dominant players would avoid the problem that general opt-in requirements might lead to users favoring large players to avoid the transaction costs of dealing with multiple, smaller players for their online needs. $^{156}$

One other way to address the fundamental information asymmetry between Google and its users in pricing the value of user data ${ }^{157}$ would be to adopt proposals that would require greater

153. Avi Goldfarb \& Catherine E. Tucker, Privacy Regulation and Online Advertising, 57 MGMT. SCI. 57, 69-70 (2011), available at http://dspace.mit.edu /openaccess-disseminate/1721.1/64920 (study using 3.3 million survey responses to 9,596 different online ads found sixty-five percent drop in effectiveness of banner ads in Europe under Privacy Directive compared to countries without privacy regulation).

154. FED. TRADE COMM'N, supra note 151, at viii.

155. See id. at C-7.

156. See James Campbell et al., Privacy Regulation and Market Structure 2 (Aug. 15, 2013) (unpublished manuscript), available at http://ssrn.com/abstract $=1729405$ (arguing that general privacy rules favor larger companies).

157. Alexander Furnas, It's Not All About You: What Privacy Advocates Don't Get About Data Tracking on the Web, ATLAnTiC (Mar. 15, 2012, 3:23 PM), http://www .theatlantic.com/technology/archive/2012/03/its-not-all-about-you-what-privacy 
transparency in how Google monetizes that data, such as regular reports on the cost per click or other payments to Google based on user activities. ${ }^{158}$ Such information, along with greater data portability between services, might actually encourage a market where users "vote with their feet"-or, more accurately, their data-and demand either a greater share of Google's profits based on that data, switch to competing providers for a better deal, or withhold their data altogether after recognizing the pervasive use by third parties that they may not want tracking them. Any of those outcomes would lessen Google's power over user data and lessen the consumer harm from that control.

Google accepting some forms of public interest responsibilities and regulation, potentially in the form of a consent decree as an alternative to divestiture of product assets, might open the doorway for a more fundamental restructuring of Google's guardianship of user data to reduce and ideally eliminate the pervasive consumer harms from data misuse by its advertisers. A clear first step would be to bar Google from engaging in price discrimination itself or from knowingly facilitating price discrimination where different groups are secretly offered different prices by its advertisers. As Stiglitz and Salop argue, a "rational economic planner"-in this case a government-backed consent antitrust decree-could economize on wasteful information-seeking costs by "eliminating the price dispersion" associated with price discrimination. ${ }^{159}$

Such an approach to Google should also bring the company under Dodd-Frank Financial Services regulation, given the percentage of its advertising revenue derived from the financial services industry. It would be appropriate for the new CFPB to regularly audit practices by Google, such as facilitating predatory price discrimination and other financial scams online, which harm consumers. The CFPB is tasked not only with regulating abuses by the banking industry, but it is also required to restrain abuses by larger nonbank participants in the financial system. ${ }^{160}$ Precisely

-advocates-dont-get-about-data-tracking-on-the-web/254533/ ("The data collectors have more information than those they are they are [sic] collecting the data from; the persuaders more [sic] power than the persuaded.").

158. Whittington \& Hoofnagle, supra note 44, at 1367 (outlining a version of such a proposal).

159. Salop \& Stiglitz, supra note 71, at 494.

160. The CFPB, in developing its rules, noted the source of this authority. 
because so many of these predatory offers are hidden from public view, the CFPB could play a prime role in improving data collection and better assessing the financial harm to consumers from these advertiser practices online. By closely overseeing how Google and other related online advertising players collect and share the personal data they control with financial services firms, many of the abuses that fueled the concern that created the CFPB in the first place could be reined in before consumers fall victim to fraudulent or discriminatory offers.

\section{B. How Government Intervention Addresses Rising Economic Inequality}

As more of the economy moves online, the importance of data mining and asymmetry of control of information becomes ever more critical in economic markets. Addressing this change calls for reevaluating both the economic assumptions underlying much recent antitrust scholarship, especially the scholarship influenced by the Chicago School, ${ }^{161}$ and taking far more active regulatory action to reverse the trends undermining user privacy and increasing economic inequality due to that rising information asymmetry.

With an eye on Google, such pressure might translate into a greater focus on sharing the financial bounty of user information with those users, serving both equity and competition. The less companies like Google are able to use privacy violations for anticompetitive purposes, the better guardian of legitimate privacy concerns such companies will become. At least one writer has compared the market failure of providing privacy and data protection to that of poor user information on food and safety a hundred years ago, explicitly highlighting the way equity and

See Defining Larger Participants in Certain Consumer Financial Product and Service Markets, 77 Fed. Reg. 9592 n.3 (Feb. 17, 2012) (codified at 12 C.F.R. $\$ 1090$ (2013)) ("Section 1024 of the Act applies to nondepository (nonbank) covered persons and expressly excludes from coverage persons described in sections 1025(a) or 1026(a) of the Act. Under section 1002(6) of the Act, a 'covered person' means '(A) any person that engages in offering or providing a consumer financial product or service; and (B) any affiliate of a person described [in (A)] if such affiliate acts as a service provider to such person."”).

161. See Manne \& Wright, supra note 20, at 179 n.21. 
consumer safety concerns of crusaders like Upton Sinclair should be the precedent for action today. ${ }^{162}$

What the case of Google highlights most of all is the way the data mining of individual privacy is fundamentally reshaping markets by transferring so much knowledge about user interests, behavior, and desires into a few corporate hands. Such information asymmetry is easily converted into economic inequality when one side of every transaction has so much more knowledge about the other during bargaining. The last four decades have seen a steady increase in economic inequality, ${ }^{163}$ which is only partially explained by standard explanations centered on the rise of economic returns to education, globalized trade, and political changes. The increasing information asymmetry in consumer markets, driven by data mining and facilitated by online services such as Google, may be an additional significant cause of this overall increase in economic inequality. Internet visionary Jaron Lanier sums up the change as "wealth is measured by how close you are to one of the big servers" and Google sits on one of the largest network of servers in the world acting as "private spying agencies" on behalf of its advertising clients. ${ }^{16}$

Government authorities using antitrust and other regulatory tools can stem at least part of this trend by restoring a degree of control by individuals over what personal data is shared online and the financial terms on which that data is shared. This in turn can eliminate some of the information-based inequality in the modern marketplace that is driving the overall economic inequality. If nothing else, a broad antitrust investigation of Google can be a chance for a much broader public debate on the abuses of data mining online and how to make all markets work more fairly for average working families.

162. Benjamin R. Sachs, Note, Consumerism and Information Privacy: How Upton Sinclair Can Again Save Us from Ourselves, 95 VA. L. REv. 205, 239-50 (2009) (suggesting a tort liability standard for companies experiencing data breaches to force them to tighten security for users).

163. Kathy Ruffing, Ctr. on Budget \& Policy Priorities, "Gini Index" from Census Confirms Rising Inequality over Four Decades, OfF THE CHARTs (Sept. 19, 2013, 4:10 PM), http://www.offthechartsblog.org/gini-index-from-census-confirms -rising-inequality-over-four-decades /.

164. Brockman, supra note 11. 